\title{
Purification performances of common reed beds based on the residence time: Case of Benin
}

\author{
H. E. J. DEGUENON, P. HOUNKPE, M. P. AINA, J. ADOUNKPE, D. C.K. SOHOUNHLOUE \\ Laboratoire des Sciences et Techniques de l'Eau / Laboratoire d'Étude et de Recherche en Chimie Appliquée - École \\ Polytechnique d'Abomey-Calavi / Université d'Abomey-Calavi, 01 BP 2009, Cotonou, Bénin République \\ Corresponding author email: marnickson@yahoo.fr
}

Original submitted in on $11^{\text {th }}$ July 2013 Published online at www.m.elewa.org on 30 th November 2013.

https://dx.doi.org/10.4314/iab.v71i1.98812

\begin{abstract}
Introduction: To avoid ecological and human disasters due to the release of huge amounts of domestic waste, wastewater treatment facilities must be built immediately. One solution is to apply an organic treatment technology. Organic treatments are cheap, efficient, and require little electric energy.

Objective: This study aims to determine the purification performances of common reed beds in order to facilitate their implementation in Benin.

Methodology and Results: A test station, which utilizes vertical flow filters planted with phragmites, was built to treat the Abomey-Calavi campus's domestic sewage in Benin. This sewage treatment plant was tested for 3 months. At the beginning of the study, the untreated sewage had concentrations of $3240 \mathrm{mg} / \mathrm{L} ; 850 \mathrm{mg} / \mathrm{L} ; 7400$ $\mathrm{mg} / \mathrm{L} ; 168 \mathrm{mg} / \mathrm{L}$; and $4.5 \mathrm{mg} / \mathrm{L}$ respectively in Chemical Oxygen Demand (COD), Biochemical Oxygen Demand at 5 days of incubation $\left(\mathrm{BOD}_{5}\right)$, Total Suspended Solid (TSS), Total Kjeldahl Nitrogen (TKN), and Total Phosphorus (TP). At the end of the study, the treatment performance results showed the following removal rates: COD $(93 \%), \mathrm{BOD}_{5}(92 \%)$, TSS $(98 \%)$ and TKN $(99 \%)$. The removal rates are within the Beninese standards set by the decree $n^{\circ} 2001-109$ of April 4, 2001 which set the minimum removal rates at $75 \%, 70-90 \%$, and $90 \%$ respectively in $\mathrm{COD}, \mathrm{BOD}_{5}$, and TSS.

Conclusion and application of results: Despite the use of a single stage, good results were obtained. Indeed, this study's removal rates are within the Beninese standards. The reed bed wastewater treatment process is simple to build, to make functional and to maintain. This process is also cheap to build. Owing to its advantages, the reed bed is a solution to Beninese purification problems. Since technical service agent of the municipalities can quickly and easily build, make functional and maintain a reed bed plant.
\end{abstract}

Keywords: common reed beds, domestic wastewater

\section{INTRODUCTION}

The internal and renewable fresh water in Africa represents a yearly average of $3950 \mathrm{~km}^{3}$ (UNEP, 2006). The availability of this fresh water is disrupted, especially by demographic growth. In fact, according to the UNEP (2002), between now and
2025, two out of three people around the world will lack water and 25 African countries will be short of water. This scarcity of water will lead to competition for water between countries and regions. Furthermore, it was noticed that the available fresh 
water is increasingly polluted by domestic wastewater (Barrett et al., 1999; Girard et al., 1997; Zingoni et al., 2005). This pollution is responsible for the decrease in the quality of drinking water, hence causing the appearance of water borne diseases and increasing the cost of drinking water treatment. These water borne diseases cause the death of 5 million people yearly; $80 \%$ of which are children. The anarchic volume of domestic wastewater released increases with population density and industrial development. This released sewage is drained into natural outlets, which cannot absorb this massive flow of pollution. Several decisions were made at international conferences, particularly in Rio in 1992, to avoid the problem; pollution emissions have to be controlled (Kivaisi 2001), sewage must be treated, and the reuse of treated water must be favored to water crops. According to the INSAE (2002), Benin had a population of 6 million people in 2000; in 2012, this population would reach 9 million. In Benin, like in most of developing countries, there are almost no sewage collection networks. Only 2 households out of 100 properly drain their sewage. The rest of the population dumps its sewage straight into the environment. Wastewater management is in a very critical situation; Benin only has three wastewater treatment plants to treat all the sewage that is unloaded daily by sewage trucks. The first one is located in Ekpè and treats the wastewater collected from Cotonou. The second treatment plant is in Porto-Novo, and the last one is in Parakou. Unfortunately, the wastewater treatment plants of Porto Novo and Parakou are conventional plants; both do not work because they are not suitable for these regions. The wastewater treatment plant of Cotonou is based upon the principle of lagooning, but this plant is presently overloaded. In fact, this plant receives more organic load than it can treat. To avoid this problem, developing countries ought to search for suitable wastewater treatment processes. However, most of these countries have a tropical climate, which is conducive to microbiological development and activity in constructed wetland; the authorities should then pay more attention to this technique. Multi-criteria analyses show that the reed beds are a suitable technique for third-world countries that have warm and tropical climate (Denny, 1997; Haberl, 1999; Kivaisi, 2001 quoted in Konnerup et al., 2008). Moreover, these reed beds are easy to build and maintain while their efficiency has been proven in developed countries. The mechanism of the reed bed treatment is known, and has been described by many researchers such as Salt et al.,1998; Williams, 2002; Vymazal, 2005; Imfeld et al.,2009 quoted in Reiche et al.,2010. This mechanism is based on physical, chemical, and biological processes (degradation by microorganisms in the root system, absorption, and plant metabolism) Calheiros et al., 2009. According to Poulet et al., 2004 reed bed wastewater treatment is based on the fixed cultivated land principle. In other words, it is an aerobic biological treatment in a thin-to-coarse granular system. The granular system is not renewed or washed. The treatment comprises of filtration and biological degradation in the presence of oxygen. There are two kinds of reed bed depending on the flow. This study was carried out only on vertical flow filters. In Benin, up until now, no reed bed wastewater treatment plant has been built. This study will thus consist of testing the vertical flow reed bed wastewater treatment process, and thus its efficiency and its feasibility in Benin. Sewage in Ivory Coast and in Tunisia is very concentrated; their values are much higher than the standard values. Sewage in India is concentrated and is within the range of the standard values. Finally, wastewater in Thailand is only slightly concentrated, its values are much lower than the standard values. 
Table 1: Characteristics of some developing countries' wastewaters

\begin{tabular}{|l|l|l|l|l|l|l|l|}
\hline Countries & Remark & COD & $\mathrm{BOD}_{5}$ & TSS & TKN & TP & References \\
\hline Units & & $\mathrm{mgO}_{2} / \mathrm{L}$ & $\mathrm{mgO}_{2} / \mathrm{L}$ & $\mathrm{mg} / \mathrm{L}$ & $\mathrm{mg} / \mathrm{L}$ & $\mathrm{mg} / \mathrm{L}$ & \\
\hline Ivory Coast & $\begin{array}{l}\text { SODECl Abidjan sewage } \\
\text { collection network (SCN) }\end{array}$ & 1256 & & 1519 & 128 & 6,2 & $\begin{array}{l}\text { Ouattara et } \\
\text { al.2008 }\end{array}$ \\
\hline Thailand & SCN of AIT & 135 & & 47 & 27 & 9,8 & $\begin{array}{l}\text { Konnerup et } \\
\text { al.2009 }\end{array}$ \\
\hline Tunisia & SCN of Joogar & 1339 & 420 & 798 & 205 & 30,7 & Kouki et al.2009 \\
\hline India & SCN of P.C.M.C., Pune & 339,7 & 206,7 & 171,2 & 31,1 & 7 & $\begin{array}{l}\text { Valipour et } \\
\text { al.2009 }\end{array}$ \\
\hline $\begin{array}{l}\text { Standard } \\
\text { values }\end{array}$ & & $300-1000$ & $150-500$ & $\begin{array}{l}100- \\
400\end{array}$ & $30-100$ & $10-25$ & \begin{tabular}{l} 
Rejsek, 2002 \\
\hline
\end{tabular} \\
\hline
\end{tabular}

\section{MATERIALS AND METHODS}

This research was conducted on the Abomey-Calavi University Campus (ACUC), located in the town of Abomey-Calavi in Benin. The domestic wastewater comes from the university's residence halls. Since there is no wastewater collection system, the sewage was taken straight from the septic tanks. Two septic tanks were used. The wastewater from the first septic tank was used to feed the reed bed system for 2 months. This wastewater was only slightly concentrated. The wastewater from the second septic tank was used to test the reed bed's purification performances. This wastewater was much more concentrated than that of the first septic tank. The experiment took place at the Drinking Water and Purification Technological Center (DWPTC) of the civil engineering department at the Engineering College of Abomey-Calavi. The small treatment plant was built and installed in this Technological Center. The ACUC enjoys a subequatorial climate. Each year is divided into four seasons: two rainy seasons and two dry seasons. The first (heavy) rainy season begins in April and ends in July. The second rainy season is short and lasts from the end of September to November. The first dry season starts in august and ends in September and the second (longer) one lasts from December to March. The filtration bed was a cubic tank made of PVC, $1.10 \mathrm{~m}$ long, $0.90 \mathrm{~m}$ wide and $1.00 \mathrm{~m}$ high. Drainpipes were installed at the bottom of the tank to collect the treated wastewater. These drainpipes are made of PVC (32 $\mathrm{mm}$ in diameter) and have slits. The slits $(5 \mathrm{~mm}$ in diameter, with $15 \mathrm{~cm}$ of space between them) are turned towards the bottom of the tank. The end of the drainpipes is linked to the atmosphere by watertight tubes, which are covered by ventilation hats. The watertight tubes, the ventilation hats, and the drainpipes have the same diameter. Watertight tests, as well as other tests, were performed before and after setting the gravel system in order to ensure that the treatment plant functioned properly. The filtration bed is comprised of three layers, according to the recommendations of Molle et al., 2005:

- The filtering layer is composed of gravel between 2 and $8 \mathrm{~m}$ min diameter and $30 \mathrm{~cm}$ in depth

- The transition layer is composed of gravelbetween 5 and $10 \mathrm{~m}$ min diameter and 15 $\mathrm{cm}$ in depth

- The drain layer is composed of gravel between 20 and $40 \mathrm{~mm}$ in diameter and $15 \mathrm{~cm}$ in depth 


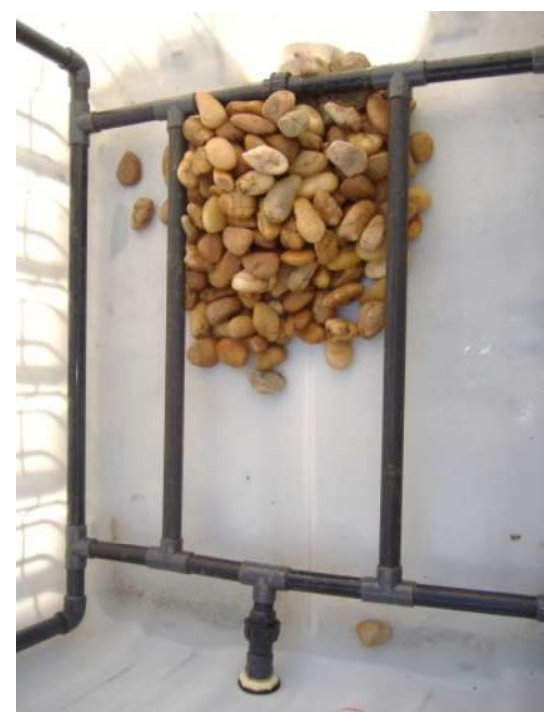

Picture 1 : The drainpipes

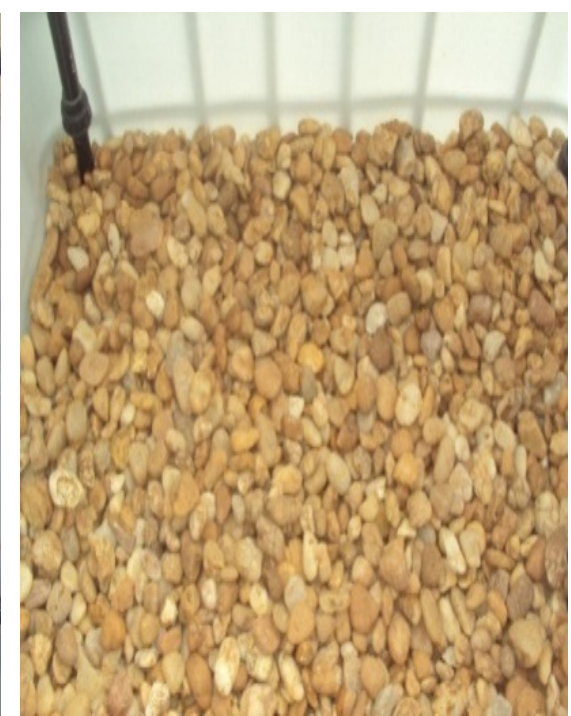

Picture 2 : The gravel

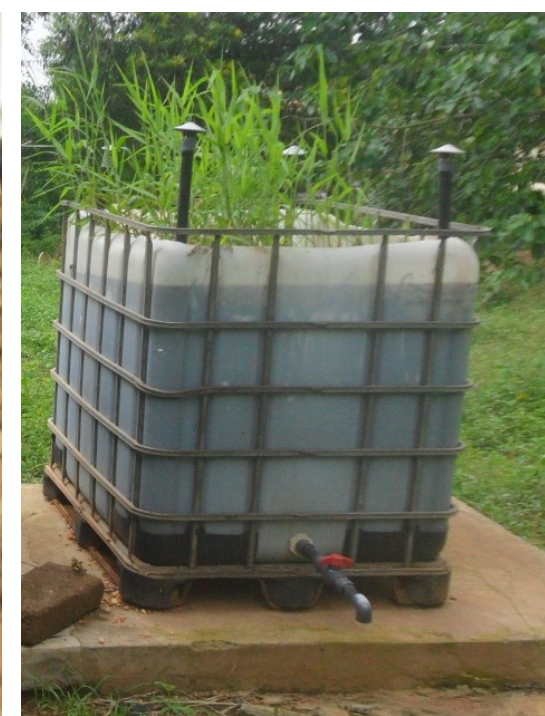

Picture 3 : The reed bed

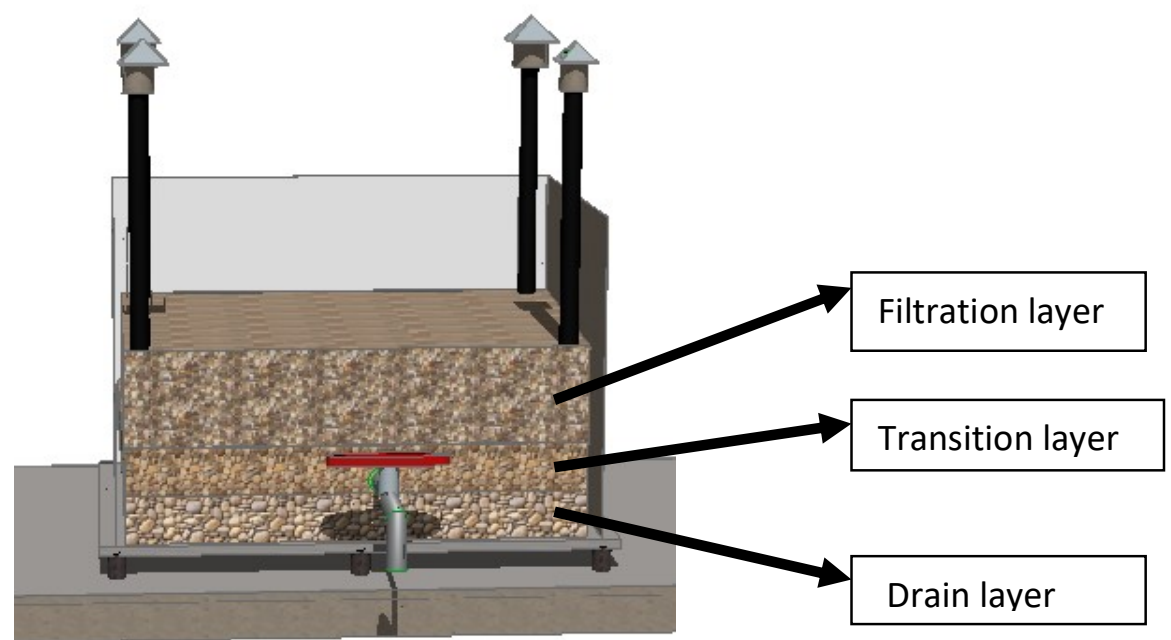

Diagram 1 : The three layers of gravel

Many types of reed grow in the town of Calavi. In this study phragmites were chosen. Young phragmite plants, which naturally grow on the campus, were dug up and transplanted to an experimentation field. The plants were often watered, especially during the dry seasons. After an year, twelve young plants from the experimentation field were dug up and transplanted into the filtration bed. The reed bed was fed for two months with slightly concentrated wastewater that comes from one of the septic tanks of university residence halls. This period is necessary because it allows plants to accustom themselves to the filtration bed and allows the biofilm to develop. The experiment was carried out based on a batch system. According to Molle et al., 2005, the volume of each batch has to permit the obtainment of a water blade, with a maximum height of $5 \mathrm{~cm}$, on top of the filtering layer. This is equivalent to a batch volume of:

$$
V=L * l * h=1.10 * 0.90 *(0.60+0.05)=0.644 \mathrm{~m}^{3}
$$

Samples of $2 \mathrm{~L}$ were taken every day at the same time. The dissolved oxygen, the $\mathrm{pH}$ and the conductivity were measured in situ with the dissolved oxygen meter (OXI 730 type WTW), the pH-meter (pH 3110 SET 3WTW type), and the conductivity meter (HI 98311 HANNA type Instrument). The turbidity was measured with a turbidimeter (Turbiquant 1100 IR type MERCK). The TKN 
concentration was determined after mineralization with selenium, according to AFNOR standards (NF EN 25663 and ISO 5663). The total phosphorus content was obtained by the use of a spectrophotometer (DR2800). To obtain the Chemical Oxygen Demand (COD) and the Total Suspended Solid (TSS), the volumetric method and the filtering method were used respectively according to AFNOR standards (NFT 90-101 and NF EN 872). As for the determination the Biochemical Oxygen Demand at 5 days of incubation $\left(\mathrm{BOD}_{5}\right)$, membrane manometers
(Oxitop) were used. Pre-packed kits (DR Hach Lange) and a spectrophotometer (DR 2800) permitted the analysis of the Total Organic Carbon (TOC) and the Dissolved Organic Carbon (DOC). Note that the sample was filtered before the DOC measurement. The yearly average rainfall is around $1200 \mathrm{~mm}$. As for the average monthly temperature, it varies between $27^{\circ} \mathrm{C}$ and $31^{\circ} \mathrm{C}$ with a tolerance of $\pm 3.2^{\circ} \mathrm{C}$ between the hottest month (March) and the coldest month (August) (IITA, 2011).

\section{STATISTICAL ANALYSIS OF THE DATA:}

Table 2: Statistical analysis on the characteristics of the residence hall wastewaters Variance analysis: one factor

Detailed report

\begin{tabular}{|l|l|l|l|l|}
\hline Groups & Number of Sample & Sum & Average & Variance \\
\hline TSS & 5 & 11467 & 2293,4 & 8305017,8 \\
\hline COD & 5 & 9226,5 & 1845,3 & 1099217,45 \\
\hline BOD $_{5}$ & 5 & 3060 & 612 & 128070 \\
\hline TKN & 5 & 514,5 & 102,9 & 2360,97 \\
\hline TP & 5 & 612,1 & 122,42 & 23901,707 \\
\hline
\end{tabular}

Variance analysis

\begin{tabular}{|l|c|c|c|c|c|c|}
\hline $\begin{array}{l}\text { Source of } \\
\text { variations }\end{array}$ & $\begin{array}{c}\text { Sum of } \\
\text { squares }\end{array}$ & $\begin{array}{c}\text { Degree } \\
\text { of } \\
\text { freedom }\end{array}$ & $\begin{array}{c}\text { Average of } \\
\text { squares }\end{array}$ & $\boldsymbol{F}$ & Probability & $\begin{array}{c}\text { Critical value for } \\
\boldsymbol{F}\end{array}$ \\
\hline Between groups & 20563898,54 & 4 & 5140974,635 & 2,689197103 & 0,06079233 & 2,866081402 \\
\hline Inside the groups & 38234271,71 & 20 & 1911713,585 & & & \\
\hline Total & 58798170,25 & 24 & & & & \\
\hline
\end{tabular}

Table 3: Statistical analysis on the characteristics of treated wastewater according to the residence time Variance analysis: one factor

Detailed report

\begin{tabular}{|l|c|c|c|c|}
\hline \multicolumn{1}{|c|}{ Groups } & Number of samples & Sum & Average & Variance \\
\hline TSS & 9 & 8520 & 946,6666667 & 5868000 \\
\hline TOC & 9 & 1328,8 & 147,6444444 & 14811,6653 \\
\hline DOC & 9 & 607,3 & 67,47777778 & 46,0219444 \\
\hline COD & 9 & 4690,6 & 521,1777778 & 1054369,69 \\
\hline BOD5 & 9 & 1562 & 173,5555556 & 67269,0278 \\
\hline TKN & 9 & 410,936 & 45,65955556 & 3524,59877 \\
\hline TP & 9 & 54,36 & 6,04 & 3,525375 \\
\hline
\end{tabular}


Variance analysis

\begin{tabular}{|l|c|c|c|c|c|c|}
\hline Source of variations & $\begin{array}{c}\text { Sum of } \\
\text { squares }\end{array}$ & $\begin{array}{c}\text { Degree } \\
\text { of } \\
\text { freedom }\end{array}$ & $\begin{array}{c}\text { Average of } \\
\text { squares }\end{array}$ & F & Probability & $\begin{array}{c}\text { Critical value } \\
\text { for F }\end{array}$ \\
\hline Between groups & 6355906,204 & 6 & 1059317,701 & 1,05810473 & 0,398546606 & 2,265567389 \\
\hline Inside groups & 56064196,25 & 56 & 1001146,362 & & & \\
\hline Total & 62420102,45 & 62 & & & & \\
\hline
\end{tabular}

\section{RESULTS AND DISCUSSION}

The values of all the parameters after the analysis of the wastewater collected from the second septic tank (table 2) confirm that this wastewater is very concentrated. Indeed, the value of the TSS is much higher than the standard values (18 times the standard maximum value of concentration). The same goes for the $\mathrm{COD}$, the $\mathrm{BOD}_{5}$, and the TKN. The wastewater collected from the first septic tank (table 2) is only slightly concentrated. That is why the TSS value is nil and the values of the COD and $\mathrm{BOD}_{5}$ are much lower than the standard values. In addition to this, the values of the wastewater collected from the second septic tank are higher than those of 2011 and 2012 except for the total phosphorus content. Hence, one can conclude that as the septic tank grows older the wastewater becomes more concentrated. In fact, when the septic tank gets older, the solid waste piles up. Nevertheless, the rain cancels this accumulation. When it rains, the rainwater dilutes the wastewater. That is how the low values observed in 2012 can be justified.

Table 4: Characteristics of the residence hall wastewaters

\begin{tabular}{|l|c|c|c|c|c|c|c|c|c|c|}
\hline Parameters & $\mathbf{T}$ & $\mathbf{p H}$ & $\mathbf{O}_{2}$ & $\mathbf{T S S}$ & $\mathbf{C O D}$ & $\mathbf{B O D}_{5}$ & $\mathbf{T O C}$ & $\mathbf{D O C}$ & $\mathbf{T K N}$ & TP \\
\hline Units & ${ }^{\circ} \mathrm{C}$ & & $\mathrm{mgO}_{2} / \mathrm{L}$ & $\mathrm{mg} / \mathrm{L}$ & $\mathrm{mgO}_{2} / \mathrm{L}$ & $\mathrm{mgO}_{2} / \mathrm{L}$ & $\mathrm{mg} / \mathrm{L}$ & $\mathrm{mg} / \mathrm{L}$ & $\mathrm{mg} / \mathrm{L}$ & $\mathrm{mg} / \mathrm{L}$ \\
\hline Septic tank 1 & 29,7 & 6,1 & 1,6 & 0 & 56,5 & 37 & & & & \\
\hline Septic tank2 & 27 & 6,5 & 0 & 7400 & 3240 & 850 & 454,5 & 75,4 & 168 & 4,5 \\
\hline $\mathbf{2 0 1 1}$ & & & & 1067 & 2644 & 1120 & & & 105 & 29,4 \\
\hline $\mathbf{2 0 1 2}$ & 26,4 & 6,3 & 0,3 & 1500 & 912 & 450 & & & 125 & 9,8 \\
\hline Standard & & & & $100-$ & $300-$ & $150-$ & & & $30-100$ & $10-25$ \\
values & & & & 400 & 1000 & 500 & & & & \\
\hline
\end{tabular}

Table 5: Characteristics of treated wastewater according to the residence time

\begin{tabular}{|l|c|c|c|c|c|c|c|c|c|c|}
\hline Parameters & $\mathbf{T}$ & $\mathbf{p H}$ & $\mathbf{0 2}$ & $\mathbf{T S S}$ & $\mathbf{C O D}$ & $\mathbf{B O D}_{5}$ & $\mathbf{T O C}$ & $\mathbf{D O C}$ & TKN & TP \\
\hline Units & ${ }^{\circ} \mathrm{C}$ & & $\mathrm{mgO}_{2} / \mathrm{L}$ & $\mathrm{mg} / \mathrm{L}$ & $\mathrm{mgO}_{2} / \mathrm{L}$ & $\mathrm{mgO}_{2} / \mathrm{L}$ & $\mathrm{mg} / \mathrm{L}$ & $\mathrm{mg} / \mathrm{L}$ & $\mathrm{mg} / \mathrm{L}$ & $\mathrm{mg} / \mathrm{L}$ \\
\hline 4 days & 27,3 & 6,9 & 1,8 & 160 & 225,3 & 70 & 105 & 64,6 & 1,312 & 7,61 \\
\hline 8 days & 25,8 & 6,7 & 2,3 & 40 & 56,5 & 70 & 78 & 64,5 & 1,5 & 9,05 \\
\hline $\begin{array}{l}\text { Rejected } \\
\text { norms }\end{array}$ & & $6-9$ & & 35 & 125 & 25 & & & 10 & 1 \\
\hline
\end{tabular}

Quality standards of wastewater in the Republic of Benin are fixed by the decree $n^{\circ} 2001-109$ of April 4, 2001. After 4 days of treatment with single stage of reed beds, only the TKN concentration of the treated wastewater is within the Beninese standards of wastewater release (Table 3 ). If the treatment lasts 8 days, more suspended solids are eliminated. However, only the concentrations in COD and in TKN are within the Beninese standards of wastewater release; the $\mathrm{BOD}_{5}$ and the $\mathrm{DOC}$ concentrations remain steady. Furthermore, TKN and Total phosphorus concentrations increase. This study shows that it is necessary to build several stages of reed beds in order to improve treatment. Indeed, when there are several stages, the treated wastewater concentrations are within standards. 

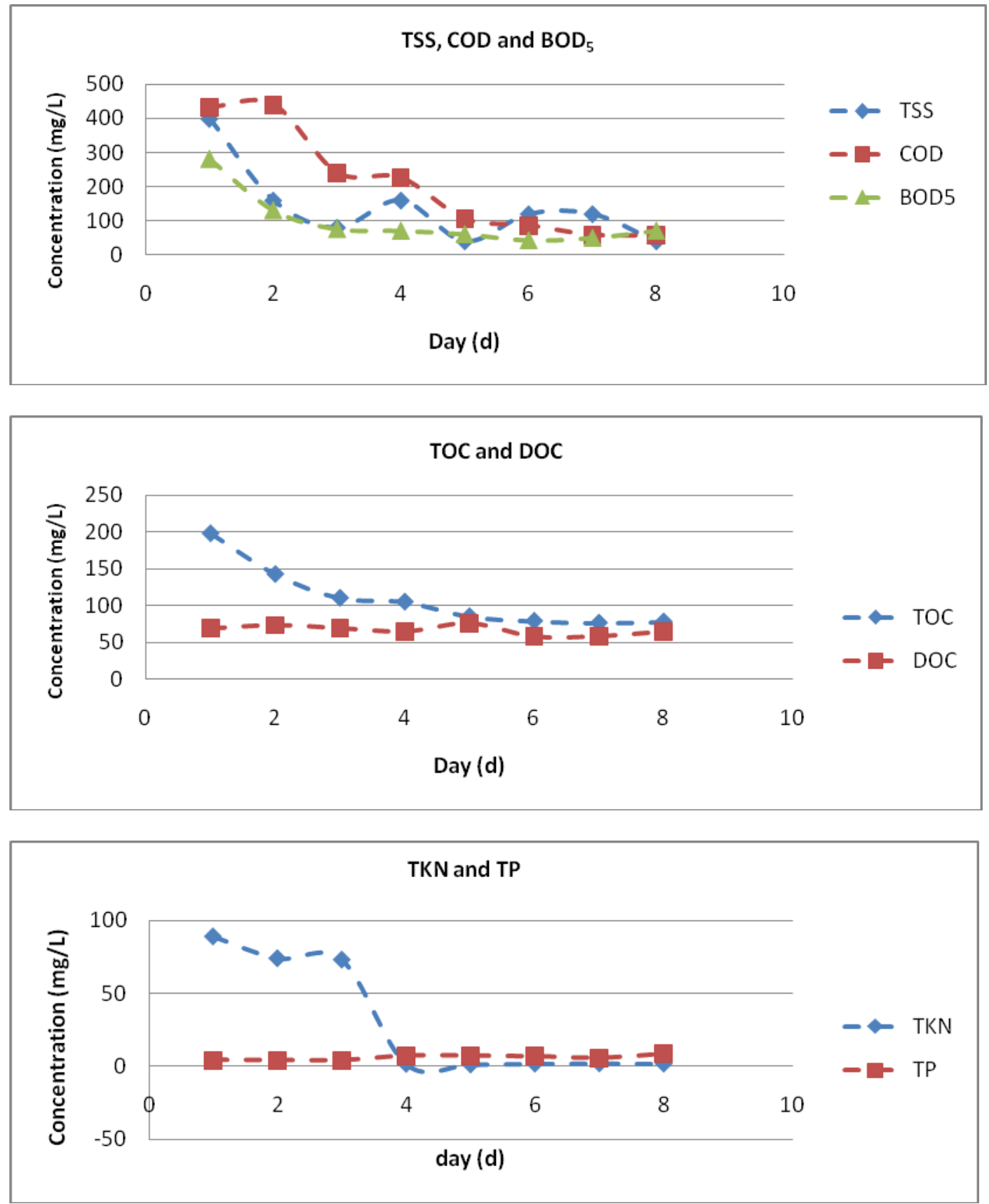

Figure 1: Evolution of concentrations according to the residence time

The concentrations (Figure 1) decrease progressively with time until stabilization at the end of the 4 days of residence time. Therefore, the optimum residence time is 4 days. Nevertheless, the DOC concentration stays steady during all the treatment. Moreover, the total phosphorus concentration stays steady during the first 4 days of treatment and increases slightly at the end of the
8 days of the treatment. This shows that the plants start degenerating from the fifth day. This phenomenon leads to the release of the phosphorus, which was absorbed by the plants before. In spite of the use of a single stage of reed beds the $\mathrm{COD}, \mathrm{BOD}_{5}$, and the TSS removal rates exceed the removal rates of the Beninese norms 


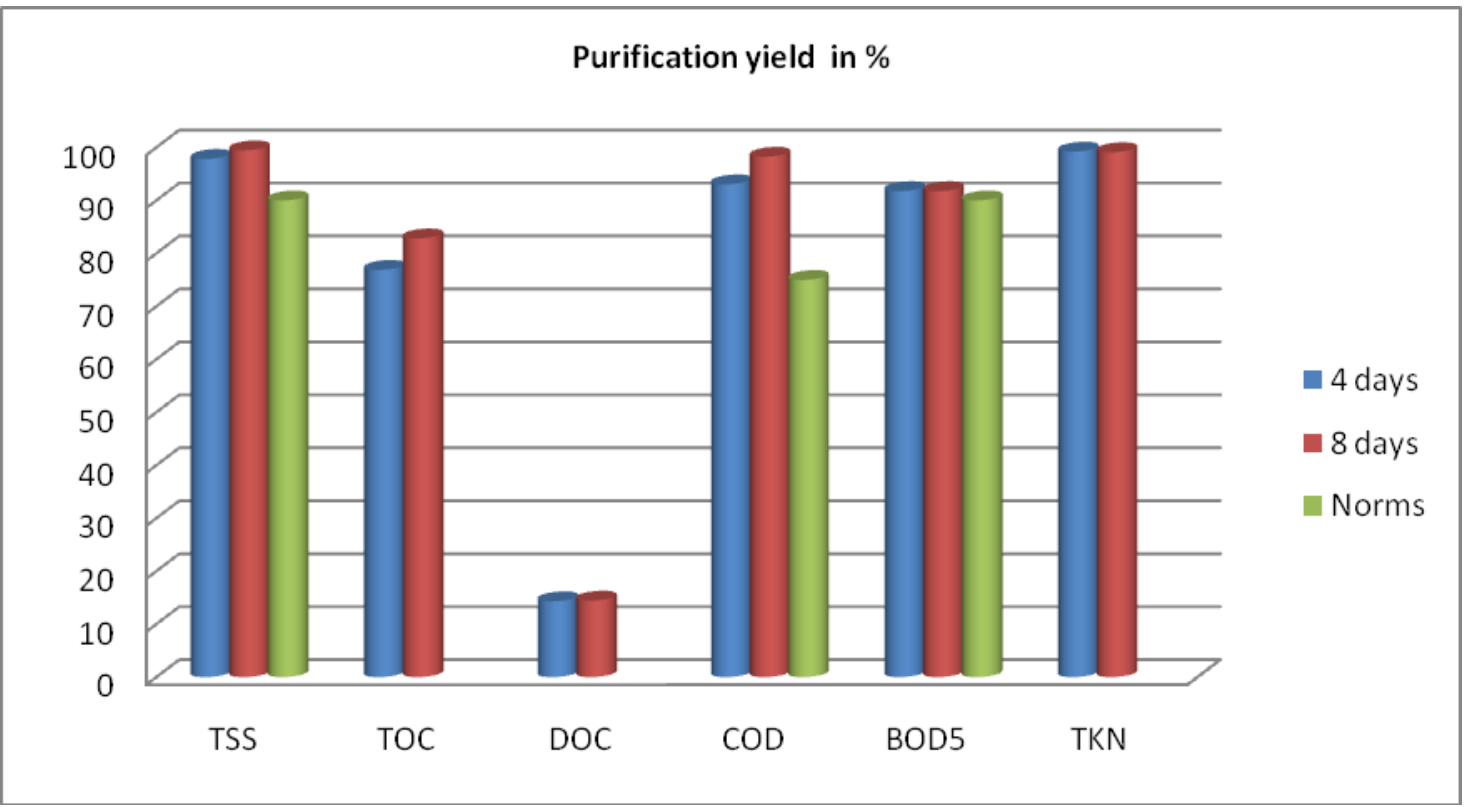

Figure 2: Purification performances according to the residence time

Table 6: Purification performances of Phragmites in other countries (with a single stage reed beds and 4 days of residence time)

\begin{tabular}{|l|c|c|c|c|c|c|}
\hline Countries & COD & BOD $_{5}$ & TSS & TKN & TP & References \\
\hline Belgium & 91 & & 94 & 65 & 52 & Rousseau et al. 2004 \\
\hline Tunisia & 89 & 93 & 98 & 38 & 72 & Kouki et al. 2009 \\
\hline India & 75 & 87 & 73 & 70 & 32 & Valipour et al. 2009 \\
\hline Italy & 94 & 94 & 67 & 92 & 75 & Morari et al. 2009 \\
\hline
\end{tabular}

The TSS removal rate, which was obtained by the present study, is the same as Kouki et al. (Table 4). The COD removal rate of the present study is slightly lower than Morari et al. The $\mathrm{BOD}_{5}$ removal rate of the present study is slightly lower than Kouki et al. and Morari et al. In terms of TKN, this study reed beds are more efficient than the other treatment plants because they eliminate up to $99 \%$ of the initial TKN. Overall, this study reed beds have a good removal rates compared to the others, except in terms of phosphorus.

Table 7: Purification performances of the Phragmites in France

\begin{tabular}{|l|l|l|l|l|l|l|l|l|}
\hline & Concentrations in mg/L & Yields in \% \\
\hline & 1 & 2 & 3 & 4 & 5 & 6 & 7 & 8 \\
\hline & $\begin{array}{l}\text { Presentstudy1 } \\
\text { stage }\end{array}$ & $\begin{array}{l}\text { Cemagref } \\
1 \text { stage }\end{array}$ & $\begin{array}{l}\text { Cemagref } \\
2 \text { stage }\end{array}$ & $\begin{array}{l}\text { Arrêté } \\
2 \text { stage }\end{array}$ & $\begin{array}{l}\text { Present } \\
\text { study1 } \\
\text { stage }\end{array}$ & $\begin{array}{l}\text { Cemagref } \\
1 \text { stage }\end{array}$ & $\begin{array}{l}\text { Cemagref1+2 } \\
\text { stages }\end{array}$ & $\begin{array}{l}\text { Arrêté } \\
1+2 \\
\text { stages }\end{array}$ \\
\hline BOD $_{5}$ & 70 & & 17 & 25 & 92 & & 94 & $\begin{array}{c}70 \text { à } \\
80\end{array}$ \\
\hline COD & 225,3 & 131 & 66 & 125 & 93 & 79 & 91 & 75 \\
\hline TSS & 160 & 33 & 14 & 35 & 98 & 86 & 95 & 90 \\
\hline TKN & 1,312 & 31 & 13 & - & 99 & 58 & 85 & - \\
\hline \multicolumn{7}{|c|}{ References : Cemagref 2004 and Liénard et al.2005 } \\
\hline
\end{tabular}

When we compare the removal rates of this study to removal rates of reed beds in France, we notice that this study removal rates are equal to the removal rates of 2 stage reed beds in France (Table 5). It is assumed that the wastewater quality (the sewage used in this study is more concentrated than in France) and the sunshine rate 
may be responsible for these results. At the beginning of the study, very concentrated sewage was taken. At the end of the treatment, the quality of the treated waste was good ( $P$-value $=0.4$ ), despite the use of a single stage of reed beds. Furthermore, in terms of final concentrations only TKN concentration is satisfying after 4 days of treatment (this concentration is lower than the Beninese

\section{REFERENCES}

AFNOR, 1988. Détermination de la demande chimique en oxygène (DCO): NF T 90-101, ISO International Norm, ISO 6060, Recueil de Normes Françaises.

AFNOR 1994. Dosage de l'azote Kjeldahl. Méthode après minéralisation au sélénium : NF EN 25663 et ISO 5663 International Norm, Recueil de Normes Françaises.

AFNOR 1996. Dosage des matières en suspension (MES). Méthode par filtration sur filtre en fibres de verre: NF EN 872, Recueil de Normes Françaises.

Aina M. P., Déguénon J., Adounkpé J., MAMA D., Sohounhloué D. C. K., 2012. Winery wastewater treatment monitored using planted wetland common reed bed International Journal of Engineering Science and Technology Vol. 4 No.08, 3898-3907.

Arrêté du 02/02/98 relatif aux prélèvements et à la consommation d'eau ainsi qu'aux émissions de toute nature des installations classées pour la protection de l'environnement soumises à autorisation en France.

Barrett M. H., Hiscock K. M., Pedley S., Lerner D. N., Tellam J. H., French M. J., 1999. Marker species for identifying urban groundwater recharge sources: A review and case study in Nottingham, UK. Water Research, vol. $33, \mathrm{n}^{\circ}$ 14, pp. 3083-3097.

Calheiros C. S. C., Duque A. F., Moura A., Henriques I. S., Correia A., Rangel A. O. S. S., Castro P. M. L., 2009. Substrate effect on bacterial communities from constructed wetlands planted with Typha latifolia treating industrial wastewater ecological engineering 35, 744-753.

Cemagref, 2004. État de la connaissance et performances des filtres plantés de roseaux en France IWA.

Décret n²001-109 du 4 avril 2001 fixant les normes de qualité des eaux résiduaires en République du BENIN. standard value of $10 \mathrm{mg} / \mathrm{l})$. After 8 days of treatment, COD concentration is also satisfying (it is lower than the Beninese standard value of $125 \mathrm{mg} / \mathrm{ll}$. The optimum residence time is 4 days. It is important to build several stages of reed beds in series in order to improve the treatment and above all to reach concentrations, which can be within the standards.

Denny P., 1997. Implementation of constructed wetlands in developing countries. Wat. Sci. Tech. 35, 2734.

Girard P., Hillaire-Marcel C., 1997. Determining the source of nitrate pollution in the Niger discontinuous aquifers using the natural $15 \mathrm{~N} / 14 \mathrm{~N}$ ratios. Journal of Hydrology, vol. 199, $\mathrm{n}^{\circ}$ 3-4, pp. 239-251.

Haberl, 1999. Constructed wetlands: a chance to solve wastewater problems in developing countries. Water Sci. Technol. 40, 11-17.

L'Institut International d'Agriculture Tropicale (IITA), 2011. Données hydrologiques.

Imfeld G., Braeckevelt M., Kuschk P., Richnow H. H., 2009. Monitoring and assessing processes of organic chemicals removal in constructed wetlands. Chemosphere 74, 349-362.

Institut National de la Statistique et de l'Analyse Économique du Bénin (INSAE), 2002. 3ème Recensement général de la population et de I'habitation, Synthèse des résultats.

Kivaisi, 2001. The potential for constructed wetlands for wastewater treatment and reuse in developing countries: a review Ecological Engineering 16, 545-560.

Konnerup D., Koottatep T., Brix H., 2009. Treatment of domestic wastewater in tropical, subsurface flow constructed wetlands planted with Canna and Heliconia Ecological Engineering 35, 248-257.

Kouki S., M'hiri F., Saidi N., Belaïd S., Hassen A., 2005. Performances of a constructed wetland treating domestic wastewaters during a macrophytes life cycle Desalination 246, 452-467.

Liénard A., Molle P., Boutin C., Dodane P-H., 2005. Traitement des eaux usées par marais artificiels : action des plantes et développement de la technique en France TSM 11.

Molle P., Lienard A., Boutin C., Merlin G., Iwema A., 2005. How to treat raw sewage with constructed wetlands: an overview of the French systems. Water Sci. Technol. 51, 11-21. 
Morari F., Giardini L., 2009.Municipal wastewater treatment with vertical flow constructed wetlands for irrigation reuse ecological engineering 35 , 643-653.

Ouattara J.-M. P., Coulibaly L., Manizan P. N., Gourene G., 2008.Traitement des Eaux Résiduaires Urbaines par un Marais Artificiel à Drainage Vertical Planté Avec Panicum Maximum sous Climat Tropical European Journal of Scientific Research ISSN 1450-216X Vol.23 No.1, 25-40.

Paulus A., 2011. Le filtre planté de roseaux Le versant vert de l'épuration des eaux usées Livre publié aux Editions du Rouergue, 2011.

Poulet J. B., Terfous A., Dap S., Ghenaim A., 2004.Station d'épuration à lits filtrants plantés de macrophytes Wastewater treatment plants with macrophytes Courrier du Savoir - N05, 103106.

Programme Des Nations Unies pour l'Environnement (PNUE), 2002. L'avenir de l'environnement en Afrique AEO. Le passé, le présent et les perspectives d'avenir.

Programme Des Nations Unies pour l'Environnement (PNUE), 2006. L'avenir de l'environnement en Afrique AEO2. Notre environnement, Notre richesse. Synthèse.

Reiche N., Lorenz W., Borsdorf H., 2010.Development and application of dynamic air chambers for measurement of volatilization fluxes of benzene and MTBE from constructed wetlands planted with common reed Chemosphere 79, 162-168.

Rejsek, 2002. Analyses des eaux, Aspects règlementaires et techniques.

Rousseau D. P. L., Vanrolleghem P. A., Pauw N. D., 2004.Constructed wetlands in Flanders: a performance analysis Ecological Engineering 23, 151-163.

Salt D.E., Smith R.D., Raskin I., 1998. Phytoremediation. Annu. Rev. Plant Phys. 49, 643-668.

Seidel, 1967.Neue Wege für die biologische Reinigung schwierige Abwässer.

Valipour A., Raman V. K., Ghole V. S., 2009. A new approach in wetland systems for domestic wastewater treatment using Phragmites sp. Ecological Engineering 35, 1797-1803.

Vymazal J., 2005. Horizontal sub-surface flow and hybrid constructed wetlands systems for wastewater treatment. Ecol. Eng. 25, 478-490.

Williams J.B., 2002. Phytoremediation in wetland ecosystems: progress, problems, and potential. Crit. Rev. Plant Sci. 21, 607-635.

Zingoni E., Love D., Magadza C., Moyce W., Musiwa K., 2005. Effects of a semi-formal urban settlement on groundwater quality Epworth (Zimbabwe): Case study and groundwater quality zoning. Physics and Chemistry of the Earth, vol. 30, pp. 680-688. 